\title{
ПСИХОСОМАТИЧНЕ ЗДОРОВ'Я ЯК ФАКТОР ПСИХОЛОГІЧНОЇ СТІЙКОСТІ ЛЮДИНИ
}

\author{
Інесса Візнюк \\ доктор психологічних наук, доцент кафедри психології та соціальної роботи \\ Вінницький державний педагогічний університет імені Михайла Коцюбинського \\ 21001, Україна, м. Вінниця, вул. Острозького, 32 \\ innavisnyuk@gmail.com, https://orcid.org/0000-0001-6538-7742
}

\begin{abstract}
Анотація
Meта дослідження полягає у визначенні особливостей психосоматичного здоров'я як фактора психологічної стійкості людини. Презентовано і апробовано відповідний комплекс методів психодіагностики. Для визначення мотиваційно-ціннісної структури особистості тест «Смисложиттєвих орієнтацій» (СЖО) Д. Леонтьєва, для виявлення соціального типу особистості - тест Д. Кейрсі. За результатами дослідження здійснено теоретичне узагальнення сучасних зарубіжних наукових підходів до проблеми психологічної стійкості особистості. Психологічна стійкість, як інтегративна полісистемна якість особистості, визначається змістом і взаємозв'язками таких структурних компонентів, як: емоційний (емоційне збудження, особистісна тривожність); соматичний (оцінка і визначення вимог ситуації щодо оптимального функціонування організму, прогноз ii можливої зміни i прийняття рішень про способи дій); і типологічна властивість нервової системи (ії сила). Виявлено чинники та структуру психологічної стійкості особистості (ставлення особистості (зокрема самооцінка), духовність особистості, емоції й почуття, когнітивна сфера, поведінкова (дійова) сфера, комунікативна сфера, самореалізація, надія, душевна сила (суб’єктність), самопізнання і саморозвиток, готовність до змін тощо). Показано, що збереження психосоматичного здоров'я можливо за умови відповідності фізіологічних, особистісних і соціальних норм психологічного потенціалу людини, в основі якого $\epsilon$ стійкість. Проаналізовано потенційний ризик розвитку соматичних хвороб щодо деструкції психіки людини. У висновках емпірично встановлено зв'язок між рівнем сформованості психологічної стійкості й психосоматичним здоров'ям у дослідженні контрольної групи та аналогічними показниками в дослідженні експериментальної групи. Доведено, що збереження психологічної стійкості особистості є актуальною проблемою, розв'язання якої означає підтримання оптимального психічного здоров'я впродовж усього життя.
\end{abstract}

Ключові слова: психологічна стійкість особистості, самоактуалізація, психосоматичні кореляти, психологічне здоров'я, рефлексивні механізми.

\section{Вступ}

Радикальні зміни в розбудові економічної, політичної й освітянської систем, сучасні вимоги до ефективної діяльності людини в професійній сфері, невпинна інтенсифікація інформаційного простору, збільшення інтелектуального навантаження, підвищення темпу життя - визначальні ознаки нового соціокультурного середовища постмодерністського суспільства. Психологічна стійкість забезпечується низкою фізіологічних, особистісних і соціальних чинників. Виникає потреба у виявленні та конкретизації характерологічних 
ресурсів людини, які б визначали іiі життєстійкість, особистісні потенціали та сприяли б збереженню психосоматичного здоров'я, готовності до змін, особистісному становленню та саморозвитку у професійній діяльності, що актуально для побудови корекційної моделі відновлення психологічної стійкості особистості у психосоматичних хворих.

B. Andrews, P.J. Watson, Z.J. Chen, R.J. Morris стверджували, що захисні механізми активуються шляхом опосередкування щодо дезадаптивного впливу на психічне здоров'я підлітків (Andrews, Watson, Chen \& Morris, 2017). J. Dagani, C. Buizza, C. Ferrari, A. Ghilardi запропонували психометричну валідизацію щодо культурної адаптації італійської анкети студентів-агресорів (Dagani, Buizza, Ferrari, \& Ghilardi, 2020). C. Juneau, N. Pellerin, E. Trives, M. Ricard, R. Shankland, M. Dambrun обгрунтували надійність анкетування за еквівалентністю: двофакторна шкала рівності (EQUA-S) (Juneau, Pellerin, Trives, Ricard, Shankland \& Dambrun, 2020). D. Acquadro Maran, T. Begotti розкрили тривожність вчителів в аспекті емоційного вигорання, відключення та їх самоефективність щодо прояву насильства на робочому місці, в складних ситуаціях підвищеного дискомфорту і ризику (Acquadro Maran \& Begotti, 2020). E. Grub, G. Wydra, M. Kaefer, V. Koellner висвітлили зміни рухового балансу в процесі стаціонарної психосоматичної реабілітації (Grub, Wydra, Kaefer, \& Koellner, 2017).

Зазначимо, що стійкість у подоланні труднощів, збереження віри в себе, упевненості в собі й у власних можливостях, досконалість психічної саморегуляції - невід’ємна частина психічного життя. Здатність зберігати постійний рівень настрою, відчувати емоційну насиченість життя, мати різносторонні інтереси, полімотиваційність життєдіяльності ознаки гармонійного характерологічного статусу людини.

Мета статті полягає у визначенні особливостей психосоматичного здоров'я як фактора психологічної стійкості людини. Гіпотеза дослідження: психологічна стійкість особистості забезпечує рівень психологічної адаптації та урівноваженості в ситуації психосоматичного порушення за умов ранньої психодіагностики і застосування комплексу психологічних заходів, спрямованих на підвищення надійності та ефективності здійснюваної діяльності. Основне завдання: дослідити особливості психосоматичного здоров'я як фактора психологічної стійкості людини.

\section{Методи дослідження}

Експериментальною базою дослідження став Вінницький державний педагогічний університет імені Михайла Коцюбинського, де генеральну вибірку склали студенти, за потенційними можливостями яких було й розкрито особливості психосоматичного здоров'я, як фактора стійкого життєзабезпечення людини. До експериментального дослідження було задіяно 204 осіб, з них 100 психосоматично здорові люди (контрольна група - КГ), яких було відібрано за результатами медичного професійно-консультативного висновку (форми № 086) i 104 особи 3 психосоматичними розладами (експериментальна група - ЕГ). Клінічний діагноз, за наявності психосоматичних розладів, було констатовано згідно з дослідницькими психодіагностичними критеріями в розділі міжнародної класифікації хвороб 10-го перегляду (MKX-10: клас V. Розлади психіки та поведінки): F 45.0 - психосоматичні розлади - й DSM$\mathrm{V}$ діагностичних критеріїв. Вік учасників експерименту 18-25 років. Всі учасники перед початком дослідження були проінформовані про умови участі в експерименті й дали згоду на участь. Експеримент був проведений за рішенням спеціалізованої вченої ради Вінницького державного педагогічного університету імені Михайла Коцюбинського (протокол № 17 від 25. 06. 2020 р.). Етичні права всіх учасників дотримано. Дослідження проводилося в 
природних умовах освітнього процесу ЗВО, із забезпеченням загальних умов участі в експерименті: однаковий час і тривалість навчання, однакові вимірювальні матеріали, що дозволяють діагностувати рівень психологічної стійкості, згідно критеріїв оцінки психосоматичного здоров'я.

Для вивчення індивідуальних особливостей збереження стану оптимального функціонування людини та ресурсів психологічної стійкості особистості ми використали низку надійних і валідних психологічних діагностик. Для визначення мотиваційно-ціннісної структури особистості - тест «Смисложиттєвих орієнтацій» (СЖО) Д. Леонтьєва, для виявлення соціального типу особистості - тест Д. Кейрсі та авторський опитувальник для вимірювання схильності до психосоматичних розладів у людини.

Відсутність психологічної стійкості особистості свідчить про ії нездатність до синтезу окремих якостей і здібностей, до самоорганізації й саморегуляції. Структурні компоненти психологічної стійкості: фактори соціального середовища та особистісні фактори - ставлення особистості (зокрема самооцінка), духовність особистості, емоції й почуття, когнітивна сфера, поведінкова (дійова) сфера, комунікативна сфера, самореалізація, надія, душевна сила (суб’єктність), самопізнання та саморозвиток, готовність до змін тощо.

Отже, психологічна стійкість як інтегративна, полісистемна якість особистості визначається змістом і взаємозв'язками таких структурних компонентів: емоційний (емоційне збудження, особистісна тривожність); соматичний (оцінка і визначення вимог ситуації щодо оптимального функціонування організму, прогноз іiї можливої зміни i прийняття рішень про способи дій); і типологічна властивість нервової системи (ії сила).

За таким підходом психологічна стійкість розглядається нами як складна інтегративна якість особистості, що забезпечує високу продуктивність діяльності та адекватну поведінку в складних життєвих обставинах, гармонізацію особистісних i соціокультурних цінностей; як складова інтелекту, що сприяє збереженню високої функціональної активності в стресогенних умовах шляхом пристосування до них або в результаті високого рівня розвитку емоційно-вольової саморегуляції; як особливість темпераменту, що дозволяє надійно виконувати людині цільові завдання діяльності за рахунок оптимального використання ресурсів нервово-психічної енергії.

\section{Результати та дискусії}

В процесі статистичної обробки даних психодіагностичних досліджень використано метод перевірки вірогідності різниць вибірок у розподілі ознак за допомогою критерію $\chi^{2}$ Пірсона, що дозволяє оцінити силу і напрям узгодженості змін між двома ознаками, та tкритерій Ст'юдента, що пов'язаний із перевіркою рівності середніх значень у двох вибірках. Загальна вибірка за номінативним маркером «психосоматичне здоров'я» була сформована за даними медичного професійно-консультативного висновку (форми № 086). За допомогою авторського психодіагностичного опитувальника шляхом використання кількісних і якісних критеріїв оцінки було відібрано осіб із психосоматичними порушеннями та виділено їх у три групи: особи з серцево-судинними вадами (CC), з дисфункцією шлунково-кишкового тракту (ШКТ) і недоліками шкірних покривів (ШП).

Результати розподілу типів за психосоматичною ознакою подані в табл. 1.

Згаданий апробований авторський опитувальник призначений для вимірювання схильності до психосоматичних розладів у людини, за допомогою якого виокремлюємо наявність соматичних скарг за кардіологічним типом, порушень шкіряного покриву i 
дисфункції органів ШКТ. Інші системи органів організму людини нами не аналізувалися, оскільки були відсутні посилання на них під час анкетування і співбесіди з респондентами.

Таблищя 1

Загальна картина психологічних корелятів соматичних порушень

\begin{tabular}{|c|c|c|c|c|}
\hline \multirow[b]{2}{*}{ 3/ח } & \multirow{2}{*}{$\begin{array}{c}\text { Чинники дисфункції } \\
\text { психологічних порушень }\end{array}$} & \multicolumn{3}{|c|}{ Скарги соматичного характеру } \\
\hline & & $\begin{array}{l}\text { CCC } \\
(\mathrm{y} \%)\end{array}$ & $\begin{array}{l}\text { ШКТ } \\
(\mathrm{y} \%)\end{array}$ & $\begin{array}{l}\text { Недоліки шкірних } \\
\text { покривів (у \%) }\end{array}$ \\
\hline 1. & Підвищена тривожність & $\begin{array}{c}57 \\
(59 \text { осіб) }\end{array}$ & $\begin{array}{c}35 \\
(36 \text { осіб) }\end{array}$ & $\begin{array}{c}68 \\
(71 \text { осіб })\end{array}$ \\
\hline 2. & Хвилювання за власне здоров’я & $\begin{array}{c}67 \\
(70 \text { осіб) } \\
\end{array}$ & $\begin{array}{c}56 \\
(58 \text { осіб) } \\
\end{array}$ & $\begin{array}{c}71 \\
(74 \text { осіб) }\end{array}$ \\
\hline 3. & Зневіра у лікування & $\begin{array}{c}45 \\
(47 \text { ociб })\end{array}$ & $\begin{array}{c}63 \\
(66 \text { осіб) }\end{array}$ & $\begin{array}{c}82 \\
(86 \text { осіб) }\end{array}$ \\
\hline 4. & $\begin{array}{l}\text { Постійна наявність медикаментозної } \\
\text { аптечки }\end{array}$ & $\begin{array}{c}85 \\
(89 \text { осіб) }\end{array}$ & $\begin{array}{c}63 \\
(66 \text { осіб) }\end{array}$ & $\begin{array}{c}34 \\
(35 \text { осіб) }\end{array}$ \\
\hline 5. & Гіперемія шкіри & $\begin{array}{c}34 \\
(35 \text { осіб) }\end{array}$ & $\begin{array}{c}37 \\
(40 \text { осіб) }\end{array}$ & $\begin{array}{c}46 \\
(48 \text { осіб) }\end{array}$ \\
\hline 6. & Болі у серці & $\begin{array}{c}86 \\
(90 \text { осіб }) \\
\end{array}$ & $\begin{array}{c}45 \\
(47 \text { осіб) } \\
\end{array}$ & $\begin{array}{c}34 \\
(35 \text { осіб) } \\
\end{array}$ \\
\hline 7. & Спрага & $\begin{array}{c}54 \\
(56 \text { осіб) } \\
\end{array}$ & $\begin{array}{c}62 \\
(65 \text { осіб) } \\
\end{array}$ & $\begin{array}{c}59 \\
(61 \text { осіб }) \\
\end{array}$ \\
\hline 8. & Боязнь інфікувань & $\begin{array}{c}75 \\
(78 \text { ociб) }\end{array}$ & $\begin{array}{c}72 \\
(75 \text { осіб) }\end{array}$ & $\begin{array}{c}75 \\
(78 \text { осіб) }\end{array}$ \\
\hline 9. & Постійне відчуття болю & $\begin{array}{c}43 \\
(45 \text { осіб) } \\
\end{array}$ & $\begin{array}{c}37 \\
(38 \text { осіб) } \\
\end{array}$ & $\begin{array}{c}27 \\
(28 \text { осіб }) \\
\end{array}$ \\
\hline 10. & Огида від споживання немитої їжі & $\begin{array}{c}69 \\
(72 \text { осіб) }\end{array}$ & $\begin{array}{c}75 \\
(78 \text { осіб) }\end{array}$ & $\begin{array}{c}67 \\
(70 \text { осіб) }\end{array}$ \\
\hline 11. & $\begin{array}{l}\text { Постійне } \\
\text { літератури }\end{array} \quad$ читання $\quad$ медичної & $\begin{array}{c}85 \\
(89 \text { осіб) }\end{array}$ & $\begin{array}{c}59 \\
\text { (61 осіб) }\end{array}$ & $\begin{array}{c}84 \\
\text { (88 осіб) }\end{array}$ \\
\hline
\end{tabular}

Згідно опитувальника, висока кількість балів свідчить про психосоматичну схильність у досліджуваного за такими параметрами:

- $\quad$ від 0 до 10 балів - відсутність схильності до психосоматичного розладу, що в деяких випадках може означати надання більшої уваги своєму фізичному здоров’ю i загартуванню організму;

- від 11 до 20 балів - низька схильність до захворювання, підтверджує важливість медичних обстежень і відповідальність у ставленні до власного здоров'я;

- $\quad$ від 21 до 30 балів - сильна стурбованість перед можливими захворюваннями, висока тривожність щодо власного здоров'я і реальна психосоматичну симптоматику;

- від 31 до 40 балів - висока ймовірність наявності однієї з форм психосоматичних проявів; щоб підтвердити або спростувати цей факт варто звернутися до фахівця.

За допомогою цього опитувальника було встановлено взаємозалежність розвитку психосоматичних розладів особистості й соматичних їх проявів під час виконання діяльності людини. В процесі професійного огляду було здійснено низку маніпуляцій щодо визначення працездатності стану організму досліджуваних. Ніяких психічних порушень не було знайдено. Однак, скарги на больові відчуття набували інтенсивності, що свідчить про недосконалість медичного огляду та відсутність можливості подальших тестувань в умовах 
стаціонару ВОКЛ ім. M.І. Пирогова за потребами дослідження. Відчуття болю в досліджуваних було присутнє у скаргах психосоматичного характеру й відображено у вчинках і поведінці. Симптоматика деяких порушень трактувалася в інші симптоми, подекуди спостерігалося нашарування соматичних скарг.

Виявлені особливості психосоматичних порушень дозволили отримати інформацію про чинники, що зумовлюють поведінку і прояви психічних властивостей осіб експериментальної групи, сформувати психодіагностичний інструментарій для наступного етапу дослідження. Важливим у цьому контексті є визначення стану тривожності, оцінка вагомості життєвих подій i форми реагування на них, адаптаційний потенціал, діагностика емоційної сфери досліджуваних, рівень самоактуалізації та особливості характерологічного конструкту особистості. За статевою ознакою спостерігається підвищена тривожність за таким розподілом досліджуваних (табл. 2).

Таблиия 2

Розподіл досліджуваних із підвищеною тривожністю за статевою належністю

\begin{tabular}{|l|l|l|l|l|}
\hline \multicolumn{1}{|c|}{ Статева належність } & \multicolumn{1}{|c|}{ КГ } & \multicolumn{1}{c|}{ ЕГ } & \multicolumn{1}{c|}{ Кількість } & \multicolumn{1}{c|}{ \% } \\
\hline Жінки & 56 & 67 & 123 & 60 \\
\hline Чоловіки & 44 & 37 & 81 & 40 \\
\hline Всього & 100 & 104 & 204 & 100 \\
\hline
\end{tabular}

Як видно з табл. 2, підвищена тривожність під час освітнього процесу характерна і в КГ осіб, що дозволяє зробити висновок про низьку дієвість студентів у навчанні.

Серед опитуваних переважає тенденція до консерватизму (ISFJ) $\left(\chi^{2}=29,97, \mathrm{p} \leq 0,003\right)$, комунікативності (ESFJ) $\left(\chi^{2}=15,92, p \leq 0,001\right)$ і порядку (ESTJ) $\left(\chi^{2}=14,97, p \leq 0,001\right)$.

\begin{tabular}{|l|l|l|l|} 
& \multicolumn{1}{|l}{ КГ } & ЕГ & ЕГ після корекції \\
\hline $\mathbf{1}$ & 2 & 3 & 4 \\
\hline ESTJ & 26 & 62 & 18 \\
\hline ISFJ & 14 & 45 & 20 \\
\hline ESFJ & 44 & 12 & \\
\hline
\end{tabular}

\section{Рис. 1. Узагальнені результати індивідуально-типологічних особливостей досліджуваних за методикою Д. Кейрсі}

Як бачимо з рис. 1, основними орієнтирами в житті психосоматично здорових осіб є впорядкована життєдіяльність, не обмежена простором навколишнього середовища i міжособистісними стосунками, що свідчить про високу інтегрованість і перспективи на майбутнє. Натомість в осіб із порушенням психосоматичного здоров'я помітний низький рівень потреб у порядку, плануванні, вимогливості й контролю, що свідчить про педантичність і прагматичність у характері.

На першому етапі дослідження був поданий повний розподіл у таблицях спряженості (до об'єднання парних частот), тобто порівнювались в сукупності розподіли респондентів за категоріями параметрів при різних висновках. Якщо розподіли відрізнялися між собою, то задля деталізації порівнювались пари частот між різними висновками в різних категоріях параметрів.

Системний аналіз індивідуально-типологічних особливостей досліджуваних за методикою Д. Кейрсі за результатами парних частот за повним розподілом у таблицях 
спряженості з використанням критерію $\chi^{2}$ до їх об'єднання виявив значущі критерії, які були притаманні обмежено осудним, а саме: консерватизм (ISFJ) у групі досліджуваних під час експерименту виявився досить обмежено $\left(\chi^{2}=2,97, p \leq 0,003\right)$, що свідчить про відсутність стійких намірів у дотриманні життєвих перспектив, порівняно з КГ осіб. Низька комунікативність (ESFJ) $\left(\chi^{2}=2,91, p \leq 0,001\right)$ засвідчує небажання у спілкуванні з оточуючими та прагнення до усамітнення. Відсутність за шкалою «порядок» високих показників $\left(\chi^{2}=5,68, p \leq 0,001\right)$ свідчить про неорганізованість людини в побуті, невміння організувати власну діяльність.

Особистісною відмінністю у КГ досліджуваних є прагнення до стабілізації і почуття відповідальності за свої вчинки, родину, друзів тощо. Вони є доброзичливими господарями, носіями миролюбних i дипломатичних цінностей, що виокремлює їx, як спокійних i врівноважених трудівників, що підтримують традиції своєї справи. Нижчі показники $\left(\chi^{2}=2,92, p \leq 0,003\right)$ у осіб ЕГ свідчать про недостатню організацію своїх умінь, енергії та можливостей. Вони вирізняються невизначеністю у поглядах, адже не виявляють статичності у вчинках, професійній діяльності та особистому житті. Зокрема керуються переважно відчуттями, інтуїцією і світобаченням інших людей. В осіб контрольної групи незалежність при виконанні певної діяльності виявляється у процесі прийняття власного рішення і відповідальності на основі діалогічної взаємодії. Останнім притаманні такі особистісні характеристики, як: життєва мудрість, відкритість, комунікативність і практичність, що свідчить про потенціал психологічного здоров'я, готовність до ризику. Досліджувані ЕГ відзначились низькою активністю у сфері міжособистісних стосунків, що дезорганізовує їх поведінку в системі комунікацій і підкреслює схильність до інтроверсії. Однак при проведенні психокорекційного тренінгу ці показники досить ефективно корелюються (рис.1).

За даними методики Д. Кейрсі (Viznyuk, 2020) в осіб КГ виявлені такі особливості характеру, як: стійкість, надійність, логічність, малоемоційність, уважність, терплячість, почуття обов'язку (ISTJ), волелюбність, необмеженість поглядів, гармонійна невимушеність, що відображаються у духовно-емоційній сфері у вигляді витворів мистецтва, музичних творів, танцювальної майстерності (ISFP), зберігання сімейного затишку та любові (ISTJ), освіченості (INTJ), прозорливості і поетичності (INFJ).

До характерологічних особливостей респондентів ЕГ належить також прагнення до духовного абсолютизму, догматичної віри, що проявляються в таких якостях, як: надмірна самовіддача, співчуття, ідеалістичність, боротьба зі злом за ідеали добра й справедливості (INFP), альтруїстичність, уважність до почуттів інших людей (ENFJ) тощо.

Експериментально було встановлено позитивну кореляцію психологічної стійкості 3 трансформаційним співіснуванням і негативну - 3 рівнем напруги. Способи співіснування із проблемною ситуацією вимірювались за допомогою Ways of Coping Checklist а показники напруження - через вимірювання артеріального тиску та за допомогою переліку симптомів Дж. Хопкінса. Виявилось, що життєстійкість не є конституційною предумовою виникнення хвороб, але в ЕГ з високим рівнем суб'єктивного стресу ії низькі показники $\left(0,227^{* *}, 0,257^{*}\right.$, $\left.0,215^{* *}\right) \epsilon$ предикатом розвитку соматичних захворювань (ймовірність захворювання на цей час складала 92\% (табл. 3), натомість за високих показників стійкості - менше $10 \%$. Високий рівень психологічної стійкості $(0,027 ; 0,017 ; 0,033)$ особистості пов'язаний із уявою і креативністю у звичних умовах існування. Спираючись на усвідомлену адекватну оцінку ситуації, стійкість негативно корелює із витісненням і авторитаризмом, а позитивно - 3 креативністю і схильністю до новаторства. Вона пов'язана зі стійким переживанням людиною своїх дій і обставин (радісних і цікавих), які є результатом особистісного вибору й 
ініціативи (контролю) та є стимулом до засвоєння нового. В осіб з важкими соматичними порушеннями життєстійкість набуває значення ресурсу, набутого досвіду, що дозволяє адаптуватись до безвиході, втрати смислу, відчаю. В респондентів із високими показниками життєстійкості спостерігалася дуже низька ймовірність виникнення застарілих психологічних переживань і конфліктів у сім’ї.

Таблиия 3

Взаємозв'язок між показниками психологічної стійкості (ПС) та соматичними порушеннями

\begin{tabular}{|c|c|c|c|}
\hline & ШКТ & СС & ШП \\
\hline Високі показники ПС & 0,027 & 0,017 & 0,033 \\
\hline Низькі показники ПС & $0,227^{* *}$ & $0,257^{* *}$ & $0,215^{* *}$ \\
\hline
\end{tabular}

** - кореляція $є$ значущою на рівні $\mathrm{p} \leq 0,01$

Аналіз отриманих даних за критерієм $\chi^{2}$ Пірсона (табл. 3) засвідчив наявність достовірних різниць $\left(\chi^{2}=16,87, \mathrm{p} \leq 0,01\right)$ середніх показників психологічної стійкості КГ та ЕГ. Відзначимо, що сила і глибина психосоматичних розладів зумовлені індивідуальними психологічними характеристиками особистості, рівнем психологічного розвитку, поведінковими стереотипами й особливостями самоактуалізації, специфічною реакцією на ситуацію, способом зміни внутрішнього особистісного конфлікту, ступенем стресостійкості. За результатами нашого дослідження зв'язок між нервово-психічною стійкістю і психічним здоров'ям існує, він значущий і прямий (rxy=0,359, p $\leq 0,01)$. Це здійснено завдяки аналізу кількісних статистичних даних і усієї сукупності залучених джерел.

Отже, за допомогою стратегії зіставлення констатовано, що еталонна контрольна (психосоматично здорові особи) та експериментальна (особи із психосоматичними порушеннями) групи мають суттєво різні значення та розподіл ознак психологічної стійкості. Виявлені якісні та кількісні відмінності стали основою формувальної стратегії, основним завданням якої було наближення показників членів ЕГ до показників учасників КГ - еталонної, тобто були спрямовані на відновлення психосоматичного здоров’я.

\section{Висновки}

Отож, виявлено, що психологічна стійкість, як інтегративна, полісистемна якість особистості, визначається змістом і взаємозв'язками таких структурних компонентів, як: емоційний, що поданий емоційним збудженням і особистісною тривожністю; соматичний оцінкою і встановленням вимог ситуації щодо оптимального функціонування організму, прогнозом іï можливої зміни і прийняттям рішень про способи дій; i типологічною властивістю нервової системи, що презентована її силою. В структурно-ієрархічній організації психологічної стійкості особистості важливою є здатність до саморозвитку, самоактуалізації, формування власної індивідуальності. Психологічна стійкість особистості є складною якістю особистості, синтезом окремих якостей і здібностей. Складовими психологічної стійкості є: здатність до особистісного зростання зі своєчасним i адекватним вирішенням внутрішньоособистісних конфліктів (ціннісних, мотиваційних, рольових); відносна стабільність емоційного тону і позитивного настрою; розвинена вольова регуляція.

Психодіагностичний блок психологічної стійкості перевірено у досліджуваних із захворюваннями психосоматичного генезу, в яких встановлено нижчі показники пошукової 
активності, порівняно зі здоровими однолітками. Експериментально виявлено взаємозв'язки психологічної стійкості з рівнем життєвого напруження, показники якого вимірювались за допомогою переліку симптомів Хопкінса. 3'ясувалося, що високий показник життєвого напруження не є конституційною передумовою виникнення хвороб. В осіб ЕГ з високим рівнем суб'єктивного стресу низький показник психологічної стійкості $є$ предикатом розвитку соматичних деструкцій; високі показники стійкості сприяють збереженню здоров'я. Крім того, високий рівень психологічної стійкості людини пов'язаний із розвиненою уявою і креативністю у нестандартних ситуаціях, при високому рівні напруження. Адекватне усвідомлення та оцінка ситуації, стійке переживання людиною своїх дій і обставин, які $\epsilon$ результатом особистісного вибору та відповідальності, в соматично хворих осіб з високим рівнем психологічної стійкості набувають значення ресурсу, досвіду, що дозволяє адаптуватись до проблем зі здоров'ям, гармонійно трансформуючи смисложиттєві орієнтації.

Перспективи подальших досліджень вбачаємо в уточненні та виявленні факторної ваги особистісних потенціалів, здатних забезпечити психосоматичне здоров'я у професійній діяльності людини; у визначенні чинників, які блокують психологічну стійкість особистості; в порівнянні сучасних зарубіжних і вітчизняних технологій підготовки фахівців; у вивченні питання збереження психосоматичного здоров'я як фактора психологічної стійкості людини.

\section{Лiтература}

1. Acquadro Maran, D., \& Begotti, T. (2020). A Circle of Violence: Are Burnout, Disengagement and Self-Efficacy in Non-University Teacher Victims of Workplace Violence New and Emergent Risks? Applied Sciences, 10(13), 4595. doi: 10.3390/app10134595

2. Andrews, B., Watson, P.J., Chen, Z.J., \& Morris, R.J. (2017). Postmodernism, positive psychology and post-traumatic growth within a Christian ideological surround. The Journal of Positive Psychology, 12(5), 489-500. doi: 10.1080/17439760.2016.1228004

3. Chen, G., \& Olsen, J.A. (2020). Filling the psycho-social gap in the EQ-5D: the empirical support for four bolt-on dimensions. Quality of Life Research, 29, 3119-3129.

doi: 10.1007/s11136-020-02576-5

4. Dagani, J., Buizza, C., Ferrari, C., \& Ghilardi, A. (2020). Psychometric validation and cultural adaptation of the Italian medical student stressor questionnaire. Current Psychology. doi: 10.1007/s12144-020-00922-x

5. Engel-Yeger, B. (2020). The role of poor motor coordination in predicting adults' health related quality of life. Research in Developmental Disabilities, 103, 103686. doi: 10.1016/j.ridd.2020.103686

6. Fierro-Suero, S., Almagro, B.J., \& Sáenz-López, P. (2020). Validation of the Achievement Emotions Questionnaire for Physical Education (AEQ-PE). International Journal of Environmental Research and Public Health, 17(12), 4560. doi: 10.3390/ijerph17124560

7. Grub, E., Wydra, G., Kaefer, M., \& Koellner, V. (2017). Changes of Motor Balance in the Course of an Inpatient Psychosomatic Rehabilitation. Die Rehabilitation, 56(6), 389-396.

doi: 10.1055/s-0043-121279

\section{References}

1. Acquadro Maran, D., \& Begotti, T. (2020). A Circle of Violence: Are Burnout, Disengagement and Self-Efficacy in Non-University Teacher Victims of Workplace Violence New and Emergent Risks? Applied Sciences, 10(13), 4595. doi: 10.3390/app10134595

2. Andrews, B., Watson, P.J., Chen, Z.J., \& Morris, R.J. (2017). Postmodernism, positive psychology and post-traumatic growth within a Christian ideological surround. The Journal of Positive Psychology, 12(5), 489-500. doi: 10.1080/17439760.2016.1228004

3. Chen, G., \& Olsen, J.A. (2020). Filling the psycho-social gap in the EQ-5D: the empirical support for four bolt-on dimensions. Quality of Life Research, 29, 3119-3129.

doi: $10.1007 / \mathrm{s} 11136-020-02576-5$ 
4. Dagani, J., Buizza, C., Ferrari, C., \& Ghilardi, A. (2020). Psychometric validation and cultural adaptation of the Italian medical student stressor questionnaire. Current Psychology. doi: 10.1007/s12144-020-00922-x

5. Engel-Yeger, B. (2020). The role of poor motor coordination in predicting adults' health related quality of life. Research in Developmental Disabilities, 103, 103686. doi: 10.1016/j.ridd.2020.103686

6. Fierro-Suero, S., Almagro, B.J., \& Sáenz-López, P. (2020). Validation of the Achievement Emotions Questionnaire for Physical Education (AEQ-PE). International Journal of Environmental Research and Public Health, 17(12), 4560. doi: 10.3390/ijerph17124560

7. Grub, E., Wydra, G., Kaefer, M., \& Koellner, V. (2017). Changes of Motor Balance in the Course of an Inpatient Psychosomatic Rehabilitation. Die Rehabilitation, 56(6), 389-396.

doi: 10.1055/s-0043-121279

\title{
PSYCHOSOMATIC HEALTH AS A FACTOR OF PSYCHOLOGICAL STABILITY OF HUMAN Inessa Vizniuk
}

Doctor of Sciences in Psychology, Associate Professor of the Department of Psychology and Social Work

Vinnytsia State Pedagogical University named after Mykhailo Kotsyubynsky

32, Ostroh Str., Vinnytsia, Ukraine, 21001

innavisnjuk@gmail.com, https://orcid.org/0000-0001-6538-7742

\begin{abstract}
The article is devoted to the study of the relationship between psychological stability and psychosomatic health. The purpose of the study is to determine the characteristics of psychosomatic health as the factor in a sustainable human life. Methods of measuring the manifestations of psychological stability are determined, the corresponding set of methods in psychodiagnostics is presented and tested. The motivational and value structure of personality is determined by the test "Meaning of life orientations" (SJO) adapted by D. Leontiev, the identification of the social type of personality is defined by D.Cairsey's test. According to the results of the research, a theoretical generalization of approaches to the problem of psychological stability of the individual is made. The factors and structure of psychological stability of the personality are revealed. The problem of interrelation of psychological stability of the person and psychosomatic health is considered. The preservation of psychosomatic health has proved to be possible provided that the physiological, personal and social norms of the psychological potential of man, which is based on stability. The potential risk of somatic diseases in relation to the destruction of the human psyche is analyzed. As a result of using psychocorrectional program the self-appraisal of respondents becomes stable and the necessity of self-actualization increases. It is the manifestation of the renewal of personality psychological firmness and an important indication of human resistance. The main results are introduced in educational process of higher educational establishments and secondary schools. The conclusions empirically establish a relationship between the level of formation of psychological stability and psychosomatic health in the study of the control group and similar indicators in the study of the experimental group. Maintaining the psychological stability of the individual has been proved to be an urgent problem, the solution of which means the achievement of harmonious development of the individual, maintaining optimal mental health throughout life.
\end{abstract}

Keywords: psychological stability of personality, self-actualization, psychosomatic correlates, psychological health, reflexive mechanisms. 